\title{
Correction to: Use of UPICC in Turkish Law: Replies to the Questionnaire on the Use of the UPICC in Order to Interpret or Supplement National Contract Law
}

\author{
Selim Ciger
}

\section{Correction to:}

Chapter 18 in: A. Garro, J. A. Moreno Rodríguez (eds.), Use of the UNIDROIT Principles to Interpret and Supplement Domestic Contract Law, Ius Comparatum - Global Studies in Comparative Law 51, https://doi.org/10.1007/978-3-030-54322-8_18

The original version of Chapter 18 was inadvertently published without incorporating the author's proof corrections where the author had requested to add the references Oğuz 2001, Erdem 2017 and Dayinlarli 2003.

The chapter has now been corrected and approved by the author. 